\title{
SPRINGSHED DELINEATION IN A KARST AQUIFER IN HAYS COUNTY, CENTRAL TEXAS
}

\author{
Brian A. Smith \\ Barton Springs/Edwards Aquifer Conservation District \\ 1124 Regal Row \\ Austin, Texas, 78748, USA, brians@bseacd.org \\ Brian B. Hunt \\ Barton Springs/Edwards Aquifer Conservation District \\ 1124 Regal Row \\ Austin, Texas, 78748,USA, brianh@bseacd.org \\ Marcus O. Gary \\ Edwards Aquifer Authority \\ 900 E. Quincy \\ San Antonio Texas, 78215,USA,mgary@edwardsaquifer.org
}

\section{Doug A. Wierman}

The Meadows Center for Water and the Environment, Texas State University

601 University Drive

San Marcos, Texas, 78666, USA, dawierman@aol.com

Jeff A. Watson

Zara Environmental

1707 West FM 1626

Manchaca, Texas, 78652, USA, Jeff@zaraenvironmental.com

\section{Abstract}

Hays County is experiencing some of the highest growth rates in the country, and groundwater is the primary option for water in the county. One spring in the study area, Jacob's Well, experiences periodic cessation of flow due to a combination of drought and pumping from nearby water-supply wells. Jacob's Well is important for ecological and water resources of the region. A springshed delineation study was conducted at the request of the local groundwater conservation district to identify the geographic area where strategies to protect flow at Jacob's Well from excessive pumping would be most effective. Many methods have been derived to set protection areas for water-supply wells, springs, and aquifers in karst settings. Much of the flow to Jacob's Well emanates from a large phreatic cave passage with over a mile of surveyed passages in the Cow Creek Limestone of the Middle Trinity Aquifer. The aquifer has varying degrees of karst development with conduit, fracture, and diffuse flow components. In this study we relied upon geologic structure maps, potentiometric maps, hydrographs, and a variety of water-balance analyses. Ultimately, the data indicated that the Jacob's Well springshed boundaries were best explained by the watershed boundaries for Cypress Creek, generally upgradient of the spring. This information was used to delineate a groundwater management zone, which was then recommended to the local groundwater conservation district and a local stakeholder group. Using the springshed delineation, rules have been drafted by the groundwater conservation district to limit increases in permitted pumping, to further restrict the amount of groundwater pumped during drought, and to protect springflow. This springshed delineation could also be used to develop rules or actions to protect the aquifer and Jacob's Well from sources of contamination.

\section{Introduction}

Hays County, which is situated between Austin and San Antonio, Texas, is experiencing some of the highest population growth rates in the country. With very little surface water available, Hays County depends heavily 
on the Edwards and Trinity Aquifers. In the western portions of the county, where there is no Edwards groundwater, the dominant sources of water are the Trinity Aquifers with the Middle Trinity Aquifer being the most prolific. The study area is part of the state-designated Priority Groundwater Management Area, an area expected to experience groundwater availability problems.

The State of Texas preserves and protects groundwater resources by enabling local management of pumping through groundwater conservation districts. The Hays Trinity Groundwater Conservation District (HTGCD) covers the western portion of Hays County and the study area is located entirely within the district's boundaries. Most wells in the study area are small-capacity domestic and ranch wells and are exempt from regulation. Largercapacity wells, which can be regulated, are mainly for municipal and irrigation use. Larger-capacity wells are estimated to pump $50 \%$ of the total annual volume within HTGCD, with the remainder pumped from exempt (domestic) wells. The current and anticipated increases in demand for groundwater and the resulting impacts are of

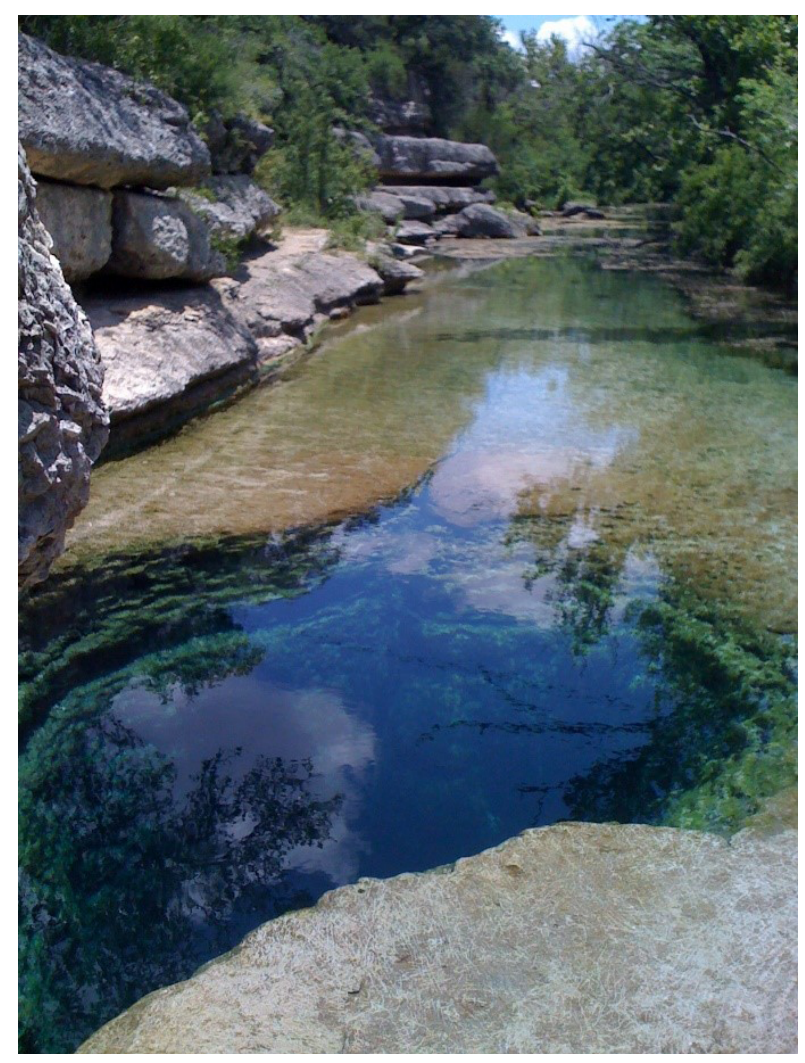

Figure 1. Jacob's Well in the foreground and view of Cypress Creek looking downstream. concern to the groundwater districts, Hays County government, and to the users of the aquifers. Impacts from pumping on springs, such as Jacob's Well (JW, Figure 1), affect the ecology of the springs, creeks, and rivers, as they change from perennial to intermittent flow. In addition, springflow sustains river flow and ultimately recharge to the downstream Edwards Aquifer. Endangered species at Barton and San Marcos Springs within the Edwards Aquifer could be impacted from reduced recharge (Smith et al., 2018).

This study was conducted, in part, to advise the HTGCD about the hydrogeologic boundaries that could delineate a springshed for Jacob's Well for regulatory purposes. If HTGCD establishes a groundwater management zone in the springshed of Jacob's Well, this portion of the Middle Trinity Aquifer could be managed differently than other portions of the aquifer. Those efforts could minimize impacts to the flow at Jacob's Well in addition to the ecology and recharge to the Edwards Aquifer.

\section{Hydrogeologic Setting}

The study area includes central and western Hays County within the Blanco River watershed (Figures 2 and 3). Cypress Creek is a tributary watershed of the Blanco River watershed. The hydrogeologic setting of the study area has been described in numerous publications including Bluntzer (1992), Wierman et al. (2008), Wierman et al. (2010), Watson et al. (2014), Hunt and Smith (2010), Hunt et al. (2017), Smith et al. (2015 and 2018a), and Gary et al. (2019). Figure 4 shows the stratigraphy of the study area.

Geologic units of the of the study area exposed at the surface consist of gently dipping Lower Cretaceous limestone and dolomite (Figure 3). Figure 5 is a cross section showing the stratigraphy of the study area. Except where remnants of the Edwards Group are present on hill tops, the dominant uppermost unit present is thin-bedded limestone and dolomite of the Upper Glen Rose member of the Glen Rose Formation. Where the Upper Glen Rose has been eroded in the Blanco River and Cypress Creek watersheds, the Lower Glen Rose is the dominant surficial unit. The Lower Glen Rose is exposed west of the Tom Creek Fault and exhibits extensive karst development within the thicker fossiliferous limestone beds (Figure 3). The Hensel Formation is a thin silty dolomite unit below the Lower Glen Rose that can behave locally 


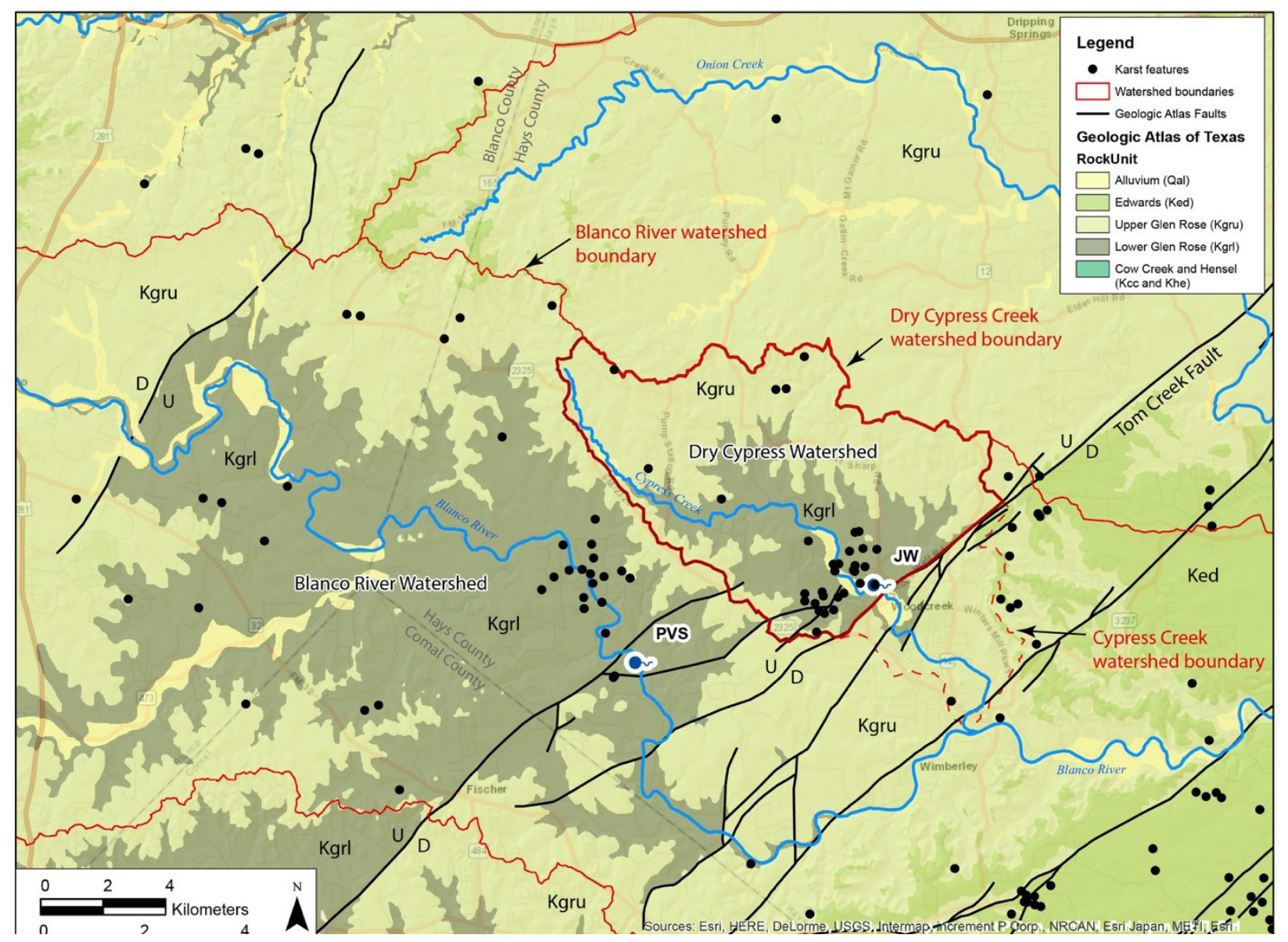

Figure 2. Geologic map of the region around Jacob's Well (JW), Pleasant Valley Spring (PVS) and the Jacob's Well watershed.

as an aquifer or an aquitard, except where breached with fractures and dissolution features. The Cow Creek Formation is mostly a grainstone (limestone). The Hammett Shale separates the Cow Creek from the underlying Sligo and Hosston formations of the Lower Trinity.

The Upper Trinity Aquifer is composed of the Upper Glen Rose limestone (Figure 4). Where present, the Upper Glen Rose generally consists of shallow perched water-table aquifers. There are often small seeps and springs associated with the Upper Glen Rose within the headwaters of drainages. The underlying Middle Trinity Aquifer is the primary aquifer in the study area and is composed of the Lower Glen Rose, Hensel, and Cow Creek formations (Figure 4). The Middle Trinity Aquifer is the water supply for most of the groundwater production in the study area and is the source of water for Jacob's Well. The Lower Glen Rose is exposed throughout much of the study area and is highly karstic. Near Ja- cob's Well, the Hensel is a locally confining unit above the Cow Creek. The Cow Creek is a highly transmissive and karstic unit and the primary aquifer unit within the Middle Trinity Aquifer.

Jacob's Well (Figure 1) is a karst spring with water discharging from the Middle Trinity Aquifer into Cypress Creek, a tributary to the Blanco River. Jacob's Well provides baseflow to Cypress Creek, which in turn provides ecological, hydrological, recreational, and financial benefits to the Wimberley region.

Since 2005, median flow values are less than 85 liters per second (L/s) (3 cubic feet per second- cfs) (Meadows, 2014). It is estimated that Jacob's Well historically provided up to 25 percent of the baseflow to the Blanco River (Gary et al., 2019). During the drought of record in the $1950 \mathrm{~s}$, springflow was measured at $74 \mathrm{~L} / \mathrm{s}(2.6 \mathrm{cfs})$ in March 1955 and estimated at about 5.6 L/s (0.2 cfs) in 


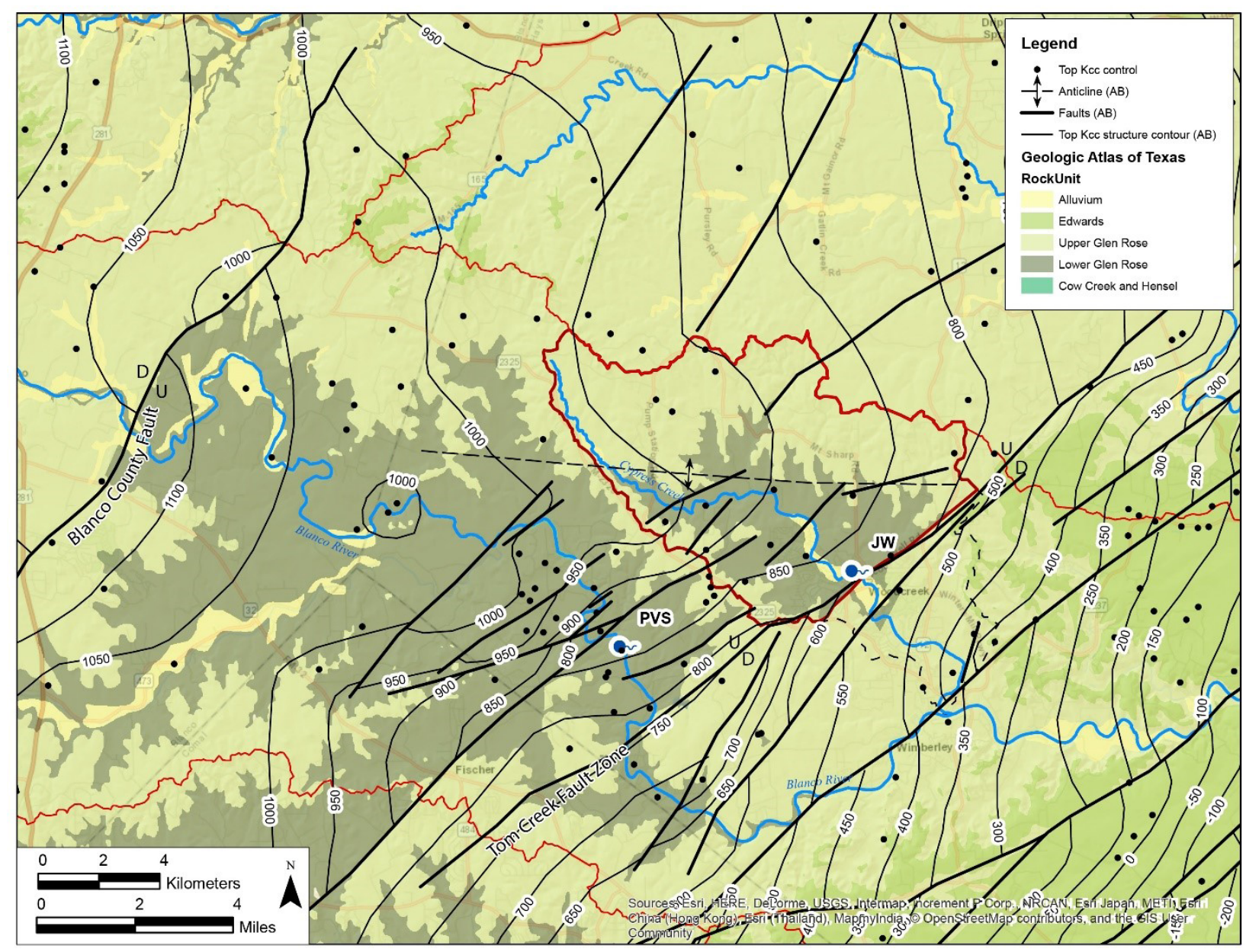

Figure 3. Geologic structure map of the region around Jacob's Well (JW). Contours intervals are in feet. $1,000 \mathrm{ft}=305 \mathrm{~m}$.

August 1955 (TBWE, 1960). Over the past 20 years, and during periods of moderate drought, increases in both permitted and exempt pumping have resulted in periodic cessation of flow at Jacob's Well. Direct measurable effects from pumping is well documented by public watersupply wells (Gary et al., 2019).

\section{Geologic Structures}

Geologic maps, outcrop studies, and geophysical logs provide the foundation of our geologic and structural mapping of the study area (BEG, 1992, Collins, 2002a, and Collins, 2002b). Structure contours of the top of the Cow Creek were created using outcrops and geophysical logs (Figure 3) (Al Broun, unpublished data).

Geologic maps and structure contours indicate the presence of a horst feature bound between a north-northwest- trending west-dipping fault within Blanco County, and a series of en-echelon east-dipping faults, known as the Tom Creek Fault Zone, near the town of Wimberley (Figure 3). Vertical displacement across the faults varies from about a meter $(3.3 \mathrm{ft})$ to about $30 \mathrm{~m}(100 \mathrm{ft})$. The Blanco River has incised deep into the horst structureexposing all three geologic units of the Middle Trinity Aquifer (Figure 3).

The geologic units of the Middle Trinity Aquifer dip gently from west to east through the study area until reaching the Tom Creek and Balcones fault zones. East of Jacob's Well the structural dips increase related to faulting (Figure 3). Some of the faults completely offset geologic and hydrogeologic units and may act as barriers to flow (Figure 5). However, faults often have variable offsets and create relay-ramp structures that can provide lateral continuity of geologic units (and flow) into and through 


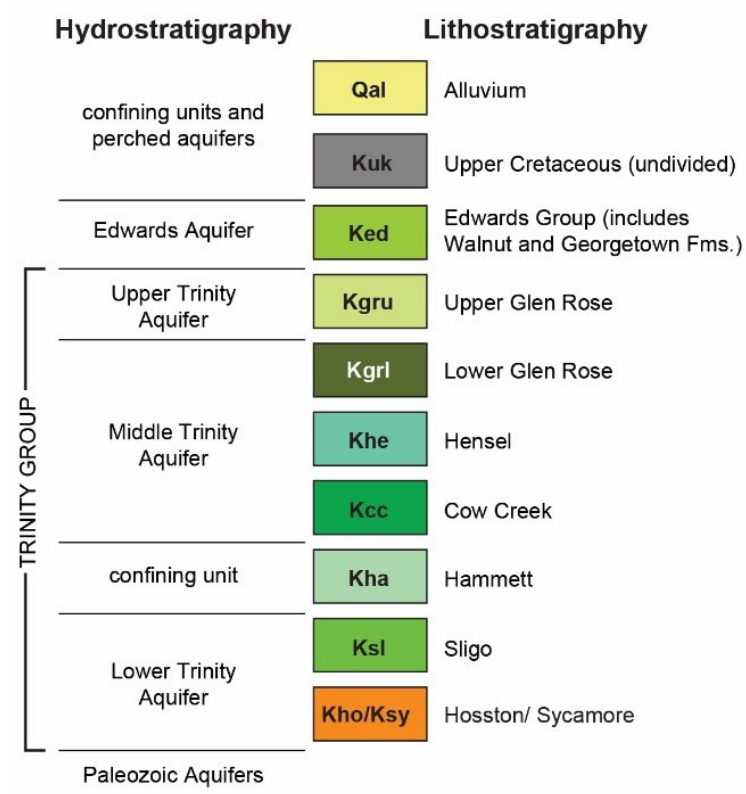

Figure 4. Stratigraphic section of the study area. the fault zone (Hunt et al., 2015). In addition, fractures associated with faults can locally increase the lateral and vertical permeability of the units.

Within the Dry Cypress Creek Watershed (the section upstream of Jacob's Well), the geologic units dip to the southeast (Figures 3 and 5). An additional structure includes an anticline trending west to east across the watershed (Wierman and others, 2010). Schumacher and Saller (2008) describe the most prevalent orientation of jointing in the direction of the region's minor stress axis $\left(310^{\circ}\right.$ to $330^{\circ}$, a northwest to southeast orientation) and perpendicular to the orientation of normal faulting. This alignment of jointing and the dip of bedding to the southeast strongly influences groundwater flow in the Middle Trinity Aquifer.

\section{Groundwater Flow}

Used with caution, potentiometric surface maps can provide important information about recharge, discharge,

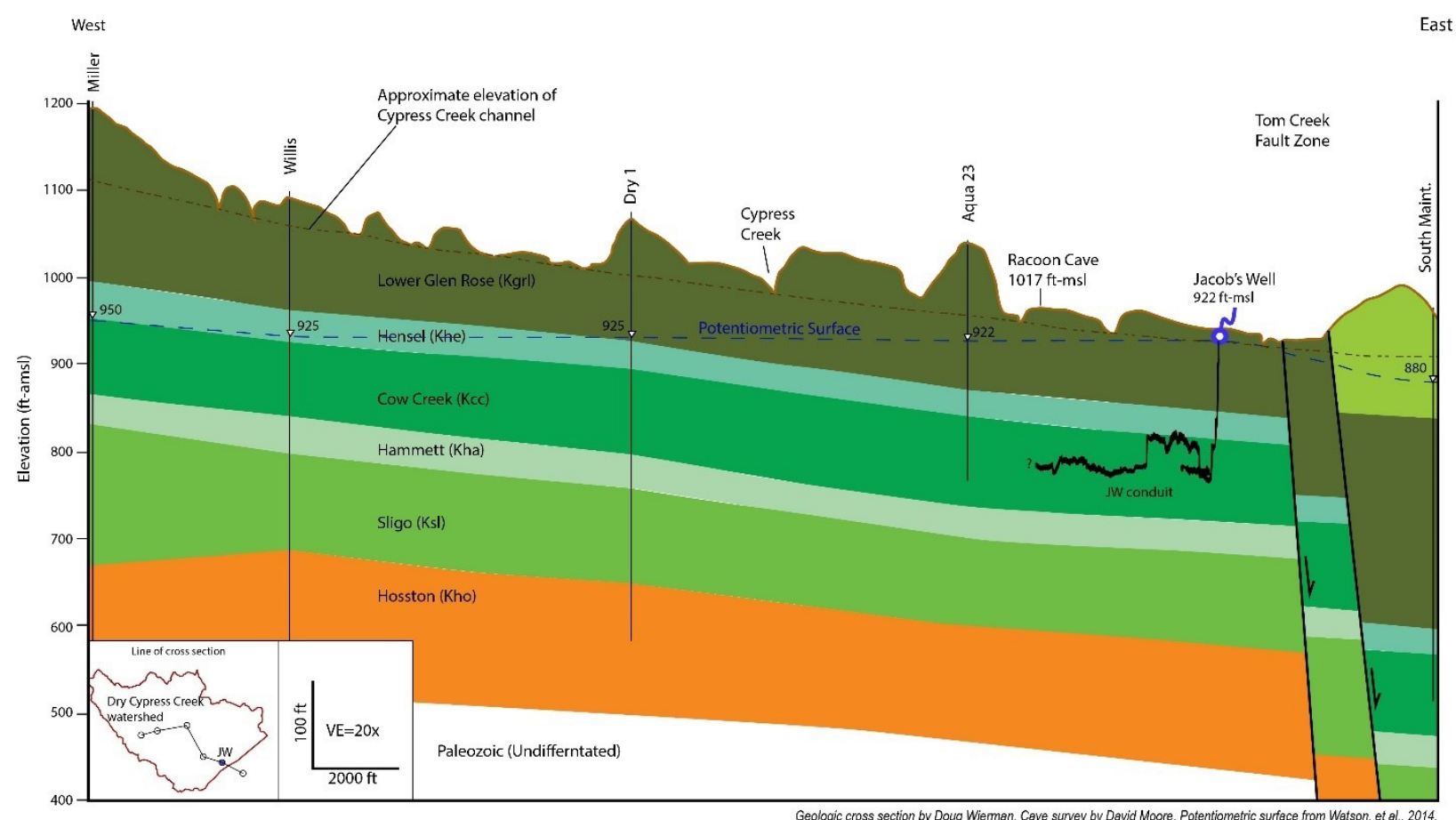

Figure 5. Cross section of study area showing general stratigraphy and location of cave passage associated with Jacob's Well. The scale on the left shows elevation above mean sea level (amsl) in 100-ft intervals, equivalent to 30-m intervals. 
aquifer storage, and the direction of groundwater flow (Kresic, 2007). Figure 6 depicts a potentiometric surface for the Middle Trinity Aquifer during March 2018 (Hunt et al., 2019) and is similar to other maps made during 2009 drought conditions (Hunt and Smith, 2010). Regional groundwater flow within the

Middle Trinity Aquifer is generally west to east from Gillespie and Blanco counties and into Hays County. Limited dye tracing has confirmed portions of this flow (Smith et al., 2018b).

The overall flow direction and potentiometric gradients generally follow the structure contour gradients, which reflect dip and faulting (Wierman et al., 2010; Figure 3). Closer to Jacob's Well, groundwater flow in the Middle Trinity Aquifer is generally from the northwest to southeast following the regional dip of the rocks. Near Ja- cob's Well, the Cow Creek is under artesian pressure, and groundwater discharges through the Hensel and the Lower Glen Rose to the surface along fractures. Flow from Jacob's Well sustains baseflow to Cypress Creek, which ultimately contributes to flow in the Blanco River. During severe drought conditions the flow in the Blanco River is the only source of continuous surface recharge to the down-dip Edwards Aquifer in Hays County (Hunt et al., 2017).

Unique features in the potentiometric map are related to structural and hydrogeologic influences. For example, the low gradient and broad potentiometric ridge within central Hays County occurs coincident within the horst complex (Figure 3). A significant trough in the potentiometric surface is located upgradient from Jacob's Well along Cypress Creek (Watson et al., 2014, Hunt et al., 2019; Figure 6). The trough indicates focused and con-

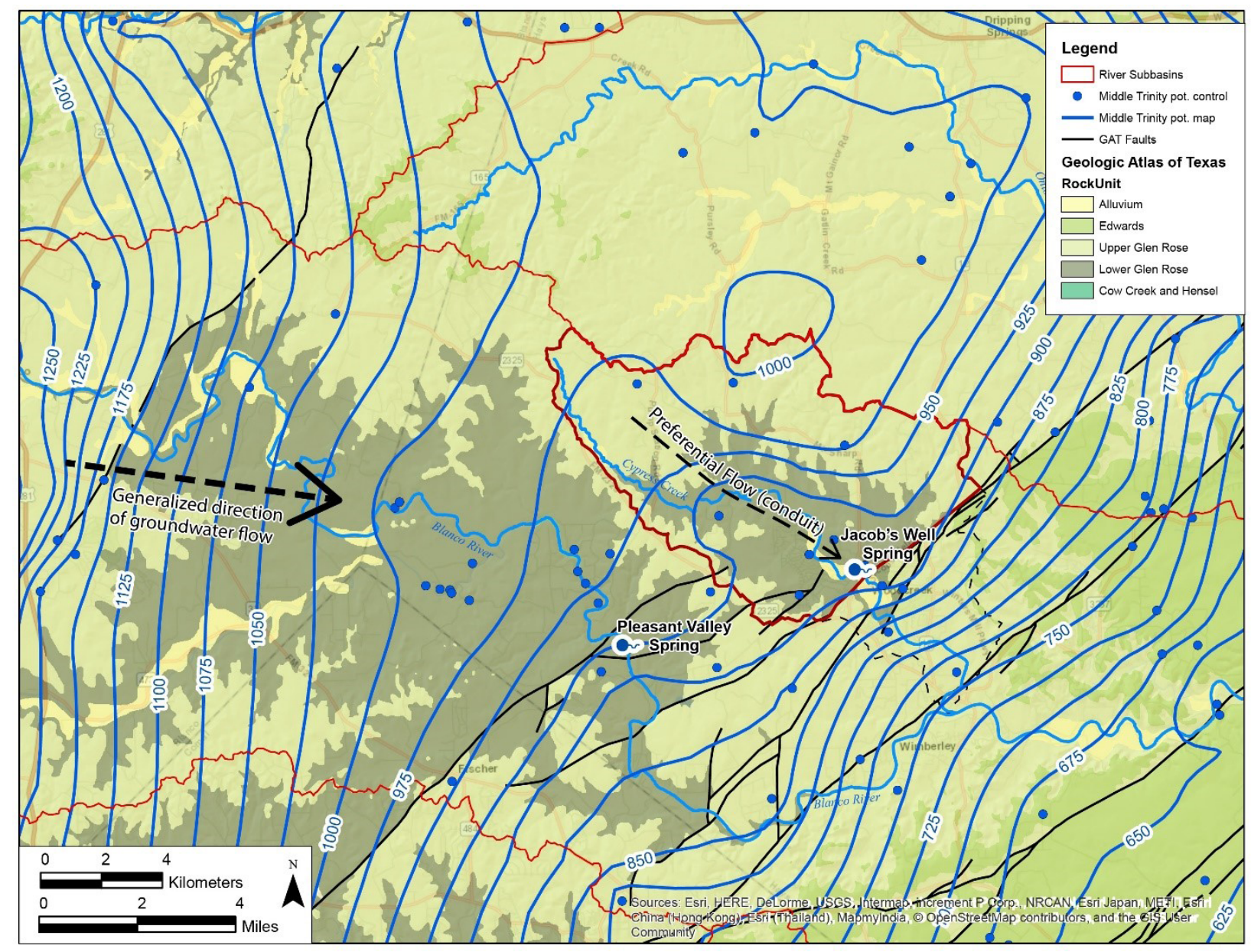

Figure 6. Potentiometric surface map of the region around Jacob's Well. Contours intervals are in feet. 1,000 ft $=305 \mathrm{~m}$. 
verging groundwater flow and is likely related to the Jacob's Well conduit, which extends northwest, parallel to Cypress Creek and beneath the trough. This conduit extends about $1,500 \mathrm{~m}(5,000 \mathrm{ft})$ to the north-northwest from Jacob's Well and is large enough for cave divers to traverse. These types of potentiometric troughs are common in karst areas (Hunt et al., 2007). A groundwater tracing study (BSEACD, 2018, Smith et al., 2018b) and other data suggest recharge into the Lower Glen Rose within Dry Cypress Creek watershed contributes to discharge at Jacob's Well along this potentiometric trough.

Faulting appears to influence the groundwater gradients (Figures 5 and 6). Steeper gradients coincident with the Tom Creek Fault Zone suggest that these faults in the zone may act as a partial barrier to eastward flow. This may be related to the larger magnitude of displacement along certain portions of the faults in this zone. However, faults do not appear to be complete barriers to eastward flow as the potentiometric contours continue to the east with variable gradients, indicating lateral groundwater flow slows in this zone. (Figures 3 and 6). Regional lateral flow to the east may be facilitated by the relay-ramp structures discussed in Hunt et al. (2015).

Along the southern boundary of Dry Cypress Creek Watershed, a potentiometric ridge, defined by the 282m (925-ft) elevation contour between Pleasant Valley Spring (about $8 \mathrm{~km}$ [5 miles] to the west) and Jacob's Well, suggests a potential hydrologic divide exists between these two major springs (Figure 6).

\section{Zones of Hydrogeologic Influence}

Three areas were delineated in the study to have certain hydrologic characteristics and varying degrees of hydrologic connection (Figure 7). Those include the Jacob's Well Springshed, Regional Recharge (Pleasant Valley

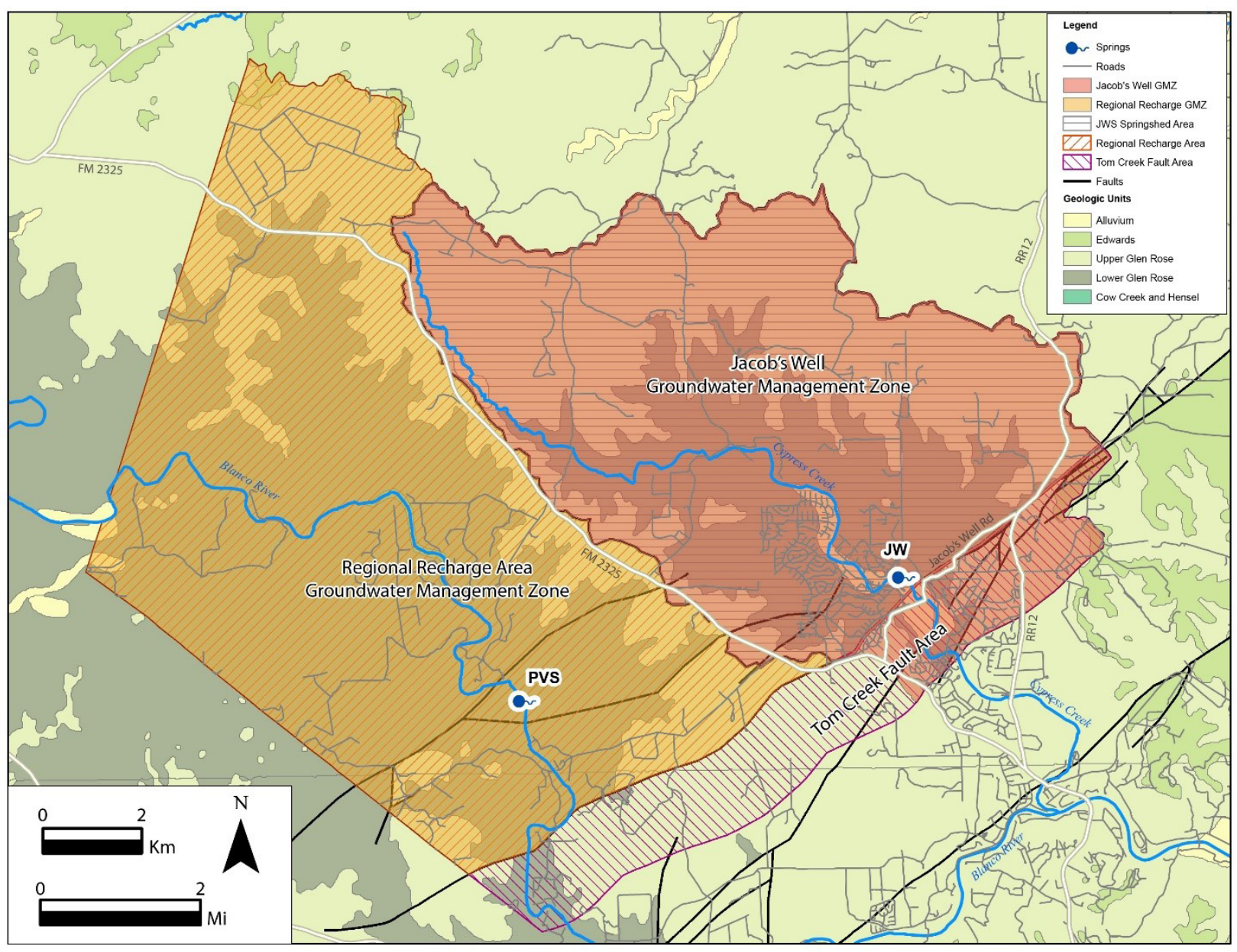

Figure 7. Location map of the three hydrogeologic areas outlined by this study. JW- Jacob's Well; PVS- Pleasant Valley Spring 
springshed) and Tom Creek Fault Areas. Each area has unique hydrologic and hydrogeologic features that were considered as part of the evaluation to delineate areas that influence Jacob's Well. These features are considered as the bases for delineating groundwater management zones.

\section{Jacob's Well Springshed Area}

The springshed of Jacob's Well was previously ill-defined with conflicting conclusions from various studies. The Blanco River was reported to be the source of recharge to Jacob's Well based on geochemistry (Steinhauer et al., 2006) and published recharge values and water budget estimates (Wierman et al., 2008). Davidson (2008) suggested two potential source areas including the area within Dry Cypress Creek Watershed and another from the Blanco River. However, Budge (2008) used correlations of NEXRAD (Next-Generation Radar) rainfall data and springflow to estimate the springshed of Jacob's Well and identified an area similar in extent to the Dry Cypress Creek Watershed.

Various data and methods help define the area that contributes flow to Jacob's Well. Geologic, structural, and potentiometric data indicate a convergence of groundwater flow to Jacob's Well that is generally constrained within the Dry Cypress Creek Watershed (Figures 3 and $5)$.

This hypothesis that the Dry Cypress Creek Watershed is the primary source of water for Jacob's Well was tested in this study as a first-order estimation of the springshed area using a variety of water-budget calculations described below.

\section{Jacob's Well Water-Balance Methods}

The springshed for Jacob's Well was estimated using a water-balance approach with recharge equaling Jacob's Well discharge. Effective annual recharge, as a percentage of precipitation, and the area of contribution (the springshed) are the unknown variables, while discharge is relatively well known due to the U.S. Geological Survey gage at Jacob's Well. Effective recharge includes all infiltrating surface water including diffuse recharge through soils and discrete recharge via karstic features.

A water-balance method was used to estimate a firstorder area for the Jacob's Well Springshed (Bonacci and
Andric, 2015). A range of assumed annual effective recharge values, as a percentage of precipitation, results in a range of potential springshed areas. An annual effective recharge of up to 25 percent of annual precipitation corresponds to a springshed size equivalent to the area of the exposed Lower Glen Rose within the Dry Cypress Creek watershed $\left(31.1 \mathrm{~km}^{2}\right.$ or $\left.12 \mathrm{mi}^{2}\right)$. An annual effective recharge of up to 10 percent of precipitation results an estimated area that is about the size of the Dry Cypress Creek Watershed $\left(80.3 \mathrm{~km}^{2}\right.$ or $\left.31 \mathrm{mi}^{2}\right)$.

Similar results were achieved using another water-balance approach consisting of NEXRAD maps of daily precipitation for the area upgradient of Jacob's Well. Daily rainfall totals were selected from six NEXRAD grids that cover the Dry Cypress Creek Watershed (about $16.1 \mathrm{~km}^{2}$ or about $6.25 \mathrm{mi}^{2}$ per grid) for a period of 561 days (1.5 years) during which Jacob's Well discharge varied from $0.0 \mathrm{~L} / \mathrm{s}(0.0 \mathrm{cfs})$ on August 22, 2011, to 6.8 $\mathrm{L} / \mathrm{s}(0.24 \mathrm{cfs})$ on March 4, 2013. Using this period minimizes effects of changing aquifer storage in a water balance equation. The volume of springflow for this period is calculated to be 9,300,000 m3 $(328,000,000 \mathrm{ft} 3)$, and the volume of rainfall for this same period was calculated for each grid. Results indicate that if 25 percent of the rainfall is recharge, then an area equal to two grids, or $32.4 \mathrm{~km}^{2}\left(12.5 \mathrm{mi}^{2}\right)$, matches Jacob's Well discharge volumetrically over the 1.5 -year period. If 10 percent of the rainfall is assumed to recharge, then an area equal to six grids, or $98.4 \mathrm{~km}^{2}\left(38 \mathrm{mi}^{2}\right)$, matches Jacob's Well volumetrically over the 1.5 -year period. These results suggest Dry Cypress Creek Watershed could account for most of the recharge area for Jacob's Well.

The two water balance methods above suggest recharge of $10-25 \%$ of annual rainfall could sustain springflow at Jacob's Well. To further test this range, a tool called ESPERE (Lanini et al., 2016) was used to test the range of estimated recharge using published empirical and analytical methods. Results indicate the annual average effective recharge as a percentage of annual rainfall ranged from 26 to 42 percent. Results of the annual effective recharge, as a percentage of rainfall, was annualized into a flow rate by assuming a recharge area of $31.1 \mathrm{~km}^{2}(12$ $\mathrm{mi}^{2}$ ) for comparison to Jacob's Well flow. Despite the three different methods, the data correlate reasonably well (R2 0.42 to 0.80 ) and indicate relatively high annual average effective recharge for the Dry Cypress Creek Watershed (Gary et al., 2019). 
The estimated effective recharge values of this study (10-25\%) are higher than regional recharge values reported from modeling of the Trinity Aquifer, which is 4 to 6 percent of precipitation (Jones et al., 2011). However, field studies in geologically similar terrains report annual effective recharge of between 13 to 34 percent of precipitation (Banta and Slattery 2011, Dugas et al., 1998). Similarly, Hauwert and Sharp (2014) report 28 percent of precipitation as effective recharge for the karstic Edwards Aquifer. Thus, the range of annual effective recharge of $10-25 \%$ appears reasonable and supports a springshed area for Jacob's Well Spring approximately equal to the area of the watershed upgradient of the spring (about $98.4 \mathrm{~km}^{2}$ or about $38 \mathrm{mi}^{2}$ ).

Geologic, structural, and potentiometric maps indicate a convergence of flow to Jacob's Well that is generally constrained within the Dry Cypress Creek Watershed. Water balance results indicate a close correlation to the outcrop area of the Lower Glen Rose within Dry Cypress Creek $\left(31.1 \mathrm{~km}^{2}\right.$ or $\left.12 \mathrm{mi}^{2}\right)$ and total Dry Cypress Creek Watershed $\left(80.3 \mathrm{~km}^{2}\right.$ or $\left.31 \mathrm{mi}^{2}\right)$ exists. Thus, the evaluations presented here generally support the hypothesis that most of the flow to Jacob's Well can be explained by recharge occurring in the Dry Cypress Creek Watershed $\left(80.3 \mathrm{~km}^{2}\right.$ or $\left.31 \mathrm{mi}^{2}\right)$. This area is defined in this report as the Jacob's Well Springshed (Figure 7).

\section{Regional Recharge Area}

Most recharge sustaining Jacob's Well originates from the Jacob's Well Springshed Area (Figure 8). However, recharge to the Cow Creek and Lower Glen Rose units of the Middle Trinity Aquifer occurs over a much larger area of western Hays, Blanco, Comal, and Kendall counties where all the Middle Trinity units are exposed and incised by the Blanco River (Figure 6).

The Regional Recharge Area (Figure 7) also corresponds to a portion of the springshed for the perennial Pleasant Valley Spring (PVS). Pleasant Valley Spring is another important Middle Trinity karst spring discharging into the Blanco River upstream of the City of Wimberley. During drought, Pleasant Valley Spring is the sole contributor of baseflow to the Blanco River in Hays County. Pleasant Valley Spring is hydrogeologically similar to Jacob's Well, however flow responses to storm events (Figure 8) and gradients shown in the potentiometric map (Figure 6) suggest different source areas for the two springs.

Along the southern boundary of Dry Cypress Creek watershed, a potentiometric ridge, defined by the 282m (925-ft) elevation contour between Pleasant Valley Spring and Jacob's Well, suggests that a potential hydrologic divide exists between these two major springs (Figure 7). Data shown in Figure 8 present a compelling case for hydrologic separation between the Blanco River/Pleasant Valley Spring and Jacob's Well. The hydrograph illustrates a response in the Blanco River at Wimberley and Pleasant Valley Spring to significant rainfall in May and June 2013. However, during that same period the hydrograph at Jacob's Well was unresponsive to the rainfall and the change in river stage in the Blanco River. This suggests that the Blanco River, under those conditions, was not a source of springflow at Jacob's Well. Other publications (Wierman et al. 2008) noted similar evidence for hydrologic separation for the reverse situation in April 2006 and again in January 2007 when discharge at Jacob's Well peaked while flow in the Blanco River remained constant. These data provide a strong indication that the Jacob's Well springshed is hydraulically separated under most conditions from the Re-

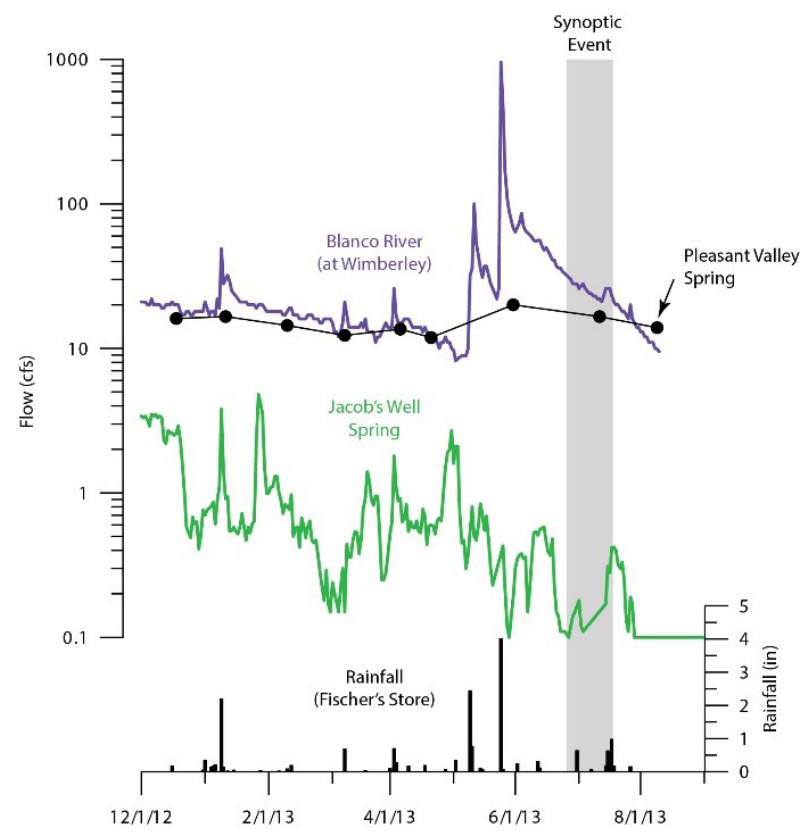

Figure 8. Hydrographs of Jacob's Well, Pleasant Valley Spring, and the Blanco River. A flow of $1.0 \mathrm{cfs}$ equals $28.3 \mathrm{~L} / \mathrm{s}$. One inch of rainfall equals $25.4 \mathrm{~mm}$. 
gional Recharge Area. However, during drought periods, the Jacob's Well Springshed Area may extend into the Regional Recharge Area.

\section{Tom Creek Fault Area}

The Tom Creek Fault Area is an area down gradient from Jacob's Well extending approximately one mile southeast of the Jacob's Well Springshed Area (Figure 7). Pumping data and water-level monitoring data collected since 2008 in the Jacob's Well Springshed Area and portions of the Tom Creek Fault Area indicate these areas are hydraulically connected (Wierman and Hunt 2018). This applies to the Tom Creek Fault Area within the Cypress Creek watershed.

\section{Water-Level Data}

Water-level data from wells in the vicinity of the Tom Creek Fault Area and Jacob's Well were evaluated to aid in characterizing the hydrogeologic relationship between structure, hydrostratigraphy, and Jacob's Well. Wells located south and east of the Tom Creek Fault Area (down dip) are more deeply confined and show a different water-level response to recharge events than up-dip wells within the Jacob's Well Springshed and Tom Creek Fault Areas (Figures 7 and 9).

During major rainfall (recharge) events, groundwater levels and discharge from Jacob's Well rise very rapidly due to the karstic nature of the Middle Trinity Aquifer (Figure 9). Groundwater elevations in wells in the Jacob's Well Springshed and Tom Creek Fault Areas within Cypress Creek (referred to as the up-dip area) have similar levels in the 280 - to $282-\mathrm{m}$ (920- to $925-\mathrm{ft})$ range and fluctuate only about a meter $(3 \mathrm{ft})$ except during major

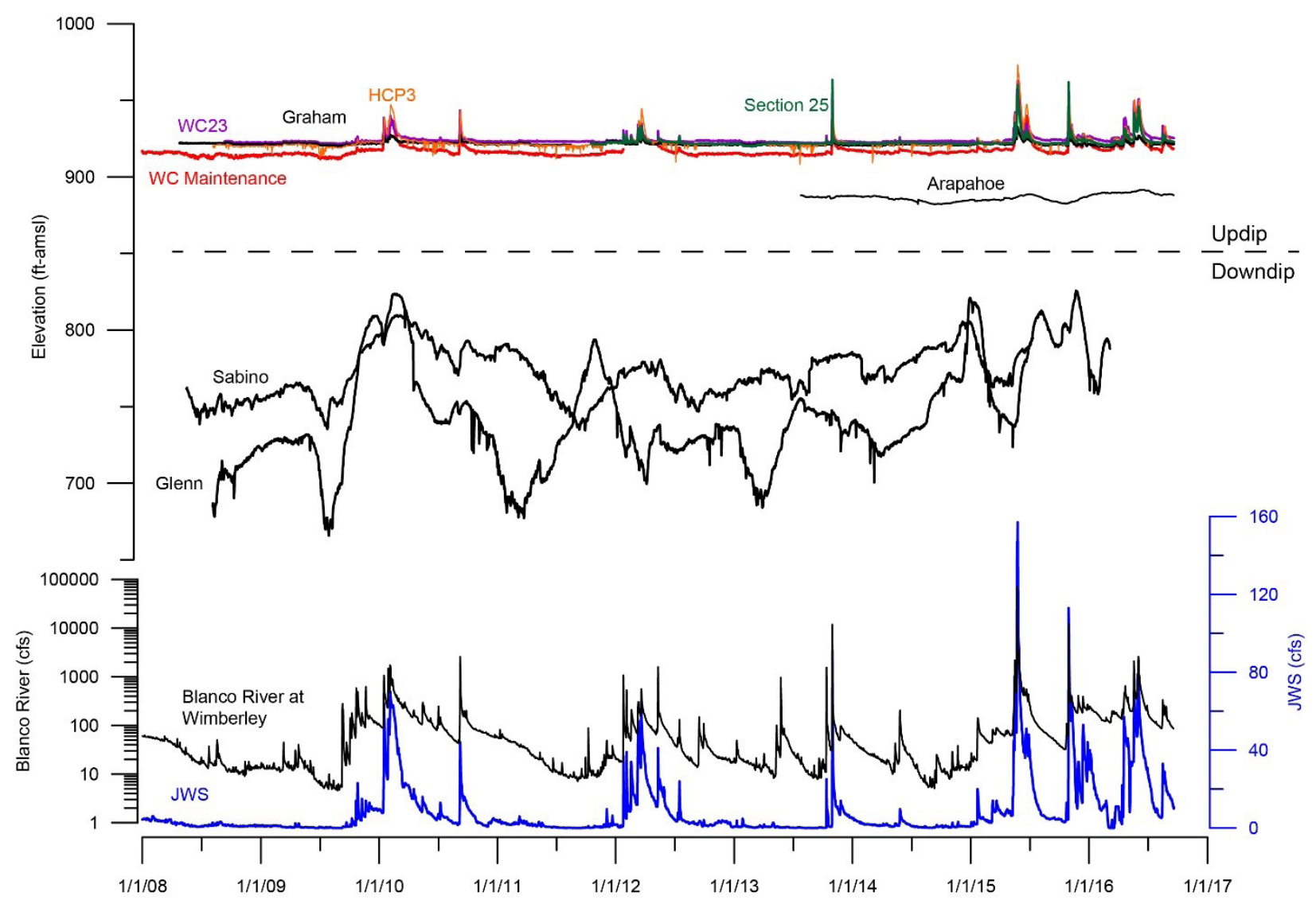

Figure 9. Hydrographs of monitor wells (transducer data) and flow from Jacob's Well and the Blanco River in cubic feet per second (cfs). Note $1.0 \mathrm{cfs}=28.3$ liters per second. The scale on the upper left shows elevation above mean sea level (amsl) in 100-ft intervals, equivalent to 30-m intervals. 
precipitation events. These potentiometric elevations are very similar to and only slightly higher than the elevation of Jacob's Well. It appears that Jacob's Well and the associated karst conduits are the dominant hydrologic features controlling the hydrologic heads upgradient of Jacob's Well (Watson and others 2014). To use an analogy from hydraulics, Jacob's Well acts as a "relief valve" for head build up in the Middle Trinity Aquifer. Dynamic and large magnitude head changes have been observed in wells in the Jacob's Well Springshed and Tom Creek Fault Areas during major precipitation events and are accompanied by rapid increases in discharge at Jacob's Well, but these increased water levels and discharge dissipate quickly.

Groundwater levels located down dip and east of the Tom Creek Fault Zone show a very different behavior to recharge events. Two Middle Trinity wells located down dip of the Tom Creek Fault Zone, Glenn and Sabino Ranch, have water-level elevations as much as 61 $\mathrm{m}(200 \mathrm{ft})$ lower than the up-dip wells (Figure 9). The difference in water levels indicates the fault is acting as a partial hydrologic barrier, or relatively impermeable restriction to horizontal flow, in that area. With as much as $100 \mathrm{~m}(330 \mathrm{ft})$ of displacement across the fault zone, the Upper Glen Rose may be juxtaposed against the Middle Trinity units (Figure 5). Water-level trends in down-dip wells generally do not mimic the stable trend of water levels in the Jacob's Well Springshed and the Tom Creek Fault Areas and appear to fluctuate more gradually with wet and drought cycles than with individual precipitation events.

The differences in water-level responses between wells in the Jacob's Well Springshed and the Tom Creek Fault Areas and wells in the down-dip area may be related to recharge and groundwater flow rates. The up-dip area is characterized by surface exposure of the Lower Glen Rose member with well-developed karst. Infiltration of precipitation is rapid, as evidenced by the rapid waterlevel rises and increased discharge at Jacob's Well (Figure 9). The Middle Trinity Aquifer monitored in the down-dip wells is significantly deeper within the geologic section resulting in longer, slower, vertical or lateral recharge pathways.

Water-level data from monitor wells and public-water supply wells show a potential hydrologic connection to Jacob's well within the Tom Creek Fault Zone, at least within the Cypress Creek Watershed as mapped in Figure 7. Water-level data from wells down-dip of the Tom Creek Fault Zone appear to have a less of a hydrologic connection to Jacob's Well (Figure 9). Accordingly, the area within the Tom Creek Fault Zone and Cypress Creek are included within the proposed Jacob's Well Management Zone (Figure 7).

\section{Summary}

Due to the rapidly growing population and demand for groundwater, Jacob's Well has become an intermittent spring. This has negative ecological and recharge impacts to the downstream resources. Limiting groundwater usage from the Middle Trinity appears to be the best mechanism to ensure adequate groundwater levels and minimal flows.

Evaluations of hydrogeology, water levels, and water balance have led to the conclusion that the boundaries of the Dry Cypress Creek Watershed are a good approximation of the Jacob's Well Springshed Area (Figure 2). Under drought conditions the Regional Recharge Area may also provide a source of water to Jacob's Well. Wells within a portion of the Tom Creek Fault Zone are thought to be in hydrologic communication with Jacob's Well. Considering all these data and hydrologic zones, Figure 7 represents the mapped hydrogeologic and management zones determined by this study. Delineation of the Jacob's Well Groundwater Management Zone is the primary conclusion from the study. Regulations for groundwater management could be developed by HTGCD that limit the amount of groundwater pumped. This could minimize negative impacts to flow at Jacob's Well and could help maintain water quality.

A recommendation has been made to HTGCD and a stakeholder group to establish a groundwater management zone for the Middle Trinity Aquifer (Gary et al., 2019). As of publication of this manuscript, HTGCD has drafted rules for this area that would restrict permits for additional groundwater and would require more significant reductions in pumping during periods of declared drought.

\section{Future Studies}

Some uncertainties remain such as the amount of groundwater flow that might come from northwest of the 
delineated springshed boundaries, locations of conduits that might influence groundwater flow, and the accuracy of the potentiometric contours that were used to help delineate the springshed boundaries. A better understanding is needed of vertical flow between hydrologic units of the Middle Trinity Aquifer. It is not known how extensively the Hensel formation confines flow from the underlying Cow Creek Limestone other than the confinement it provides at Jacob's Well. Cave divers have mapped over a mile of cave passage that extends northwest of Jacob's Well; however, the conduit system that feeds groundwater to Jacob's Well is not known beyond this mapped passage. A better understanding of recharge within the springshed and the upgradient areas northwest of the springshed are needed. Key tasks that are planned for the near future are installation of two or more monitor wells upgradient of Jacob's Well. One of those wells will be a multiport monitor well that can monitor distinct hydrogeologic zones in a single borehole. From these zones, discrete measurements of potentiometric pressure and hydraulic conductivity can be made, and groundwater samples can be collected from each zone for waterquality analyses. Additional studies are necessary to determine how long-term drawdown of the aquifer due to pumping in this region would impact spring flow. The delineation of springshed boundaries will be reevaluated when these additional studies are completed.

\section{Acknowledgments}

This paper is largely a summary of a report by a technical team consisting of the authors of this manuscript. This report was submitted to the HTGCD in July 2019 (Gary et al., 2019). In that report we received reviews and valuable comments from Robert E. Mace, Paul Bertetti, and Alex S. Broun. We would also like to thank the anonymous reviewers for their comments that considerably improved this manuscript.

\section{References}

Banta, J.R. and Slattery, R.N. 2011. Effects of Brush Management on the Hydrologic Budget and Water Quality in and Adjacent to Honey Creek State Natural Area, Comal County, Texas, 2001-10. US Geological Survey SRI Report 2011-5226, Reston, 34.

BEG- Bureau of Economic Geology. 1992. Geologic Map of Texas: University of Texas at Austin,
Virgil E. Barnes, project supervisor, Hartmann, B.M. and Scranton, D.F., cartography, scale $1: 500,000$

Bluntzer, R. L. 1992. Evaluation of the ground-water resources of the Paleozoic and Cretaceous aquifers in the Hill Country of central Texas: Texas Water Development Board Report 339, 130 p.

Bonacci O. and I. Andric. 2015. Karst spring catchment: an example from Dinaric karst, Environmental Earth Sciences, July 2015

BSEACD- Barton Springs Edwards Aquifer Conservation District. 2018. Dye Trace at Raccoon Cave near Jacob's Well Spring, Hays County, Texas. Technical Memo 2018-0831. 17 p.

Budge, T. 2008. Delineating contributing areas in Two Texas Karst Aquifers using NEXRAD rainfall Estimates. Ph.D. Dissertation, Jackson School of Geosciences, University of Texas at Austin. 189 p. 41 p.

Collins, E.W. 2002a. Geologic map of the Rough Hollow quadrangle, Texas: University of Texas at Austin, Bureau of Economic Geology, Open-File Map STATEMAP Study Area 9, scale 1:24,000.

Collins, E.W. 2002b. Geologic map of the Driftwood quadrangle, Texas: University of Texas at Austin, Bureau of Economic Geology, Open-File Map STATEMAP Study Area 9, scale 1:24,000.

Davidson, S.C. 2008. Hydrogeological characterization of baseflow to Jacob's Well spring, Hays County, Texas. Master's Thesis, Jackson School of Geosciences, University of Texas at Austin. 125 p.

Dugas, W.A., Hicks, R.A. and Wright, P. 1998. Effect of Removal of Juniperus ashei on Evapotranspiration and Runoff in the Seco Creek Watershed. Water Resources Research, 34, 1499-1506.

Gary, M.O., Hunt, B.B., Smith, B.A., Watson, J.A., and Wierman, D.A. 2019. Evaluation for the Development of a Jacob's Well Groundwater Management Zone Hays County, Texas. Technical Report prepared for the Hays Trinity Groundwater Conservation District, Hays County, Texas. Meadows Center for Water and the Environment, Texas State University at San Marcos, TX. Report: 2019-05. July 2019. 58 p. 
Hauwert, N.M. and Sharp, J.M. 2014. Measuring Autogenic Recharge over a Karst Aquifer Utilizing Eddy Covariance Evapotranspiration. Journal of Water Resource and Protection, 6, 869879.

Hunt, B.B, Smith, B.A. 2010. Spring 2009 potentiometric map of the Middle Trinity Aquifer in Groundwater Management Area 9, Central Texas. Barton Springs/Edwards Aquifer Conservation District Report of Investigations 2010-0501. 26 p.

Hunt, B.B., B.A. Smith, A. Andrews, D.A. Wierman, A.S. Broun, and M.O. Gary. 2015. Relay ramp structures and their influence on groundwater flow in the Edwards and Trinity Aquifers, Hays and Travis Counties, Central Texas, Sinkhole Conference, October 5-10, 2015, Rochester, Minnesota

Hunt, B. B., B.A. Smith, M.O. Gary, A.S. Broun, D.A. Wierman, J. Watson, and D.A. Johns. 2017. Surface-water and Groundwater Interactions in the Blanco River and Onion Creek Watersheds: Implications for the Trinity and Edwards Aquifers of Central Texas. South Texas Geological Society Bulletin, v. 57, no. 5, January 2017, p. 33-53.

Hunt, B.B., B.A. Smith, R. Gary, and Justin Camp. 2019. March 2018 Potentiometric Map of the Middle Trinity Aquifer, Central Texas. BSEACD Report of Investigations 2019-0109, 33 p.

Jones, I. C., R. Anaya, and S. C. Wade. 2011. Groundwater availability model: Hill Country portion of the Trinity Aquifer of Texas: Texas Water Development Board Report 377, Austin, $165 \mathrm{p}$.

Kresic, N., 2007, Hydrogeology and Groundwater Modeling, second edition. CRC Press, Boca Raton Florida, 807 p.

Lanini S, Caballero Y, Sequin JJ, Marechal JC. 2016, ESPERE - A multiple-method Microsoft Excel application for estimating aquifer recharge. Groundwater 54 (2): 155-156.

Meadows. 2014. Cypress Creek watershed protection plan. The Meadows Center for Water and the Environment, Texas State University, San Marcos, TX. 127 p.
Schumacher, W. and Saller, S. 2008. Cypress Creek Project-Structural analysis: Characteristics of the Glen Rose formation in and around the Cypress Creek watershed and their implications on groundwater flow. Hays Trinity Groundwater Conservation District.

Smith, B., Hunt, B., Andrews, A., Watson, J., Gary, M., Wierman, D., and Broun, A. 2015. Hydrologic Influences of the Blanco River on the Trinity and Edwards Aquifers, Central Texas, USA, in Hydrogeological and Environmental Investigations in Karst Systems, (Eds) B. Andreo, F. Carrasco, J. Duran, P. Jimenez, and J. LaMoreaux, Environmental Earth Sciences, Springer Berlin Heidelberg, Volume 1, pp 153161.

Smith, B.A., B.B. Hunt, D.A. Wierman, and M.O. Gary. 2018a. Groundwater Flow Systems of Multiple Karst Aquifers of Central Texas. In I.D. Sasowsky, M.J. Byle, and L. Land (Eds). Proceedings of the 15th Multidisciplinary Conference on Sinkholes and the Engineering and Environmental Impacts of Karst and the 3rd Appalachian Karst Symposium, National Cave and Karst Research Institute (NCKRI) Symposium 6, p 17-29.

Smith, B.A., Brian B. Hunt, Marcus Gary and Jeffery Watson. 2018b. Applying Dye Tracing to Characterize Surface-water and Groundwater Interactions in the Trinity Aquifers, Central Texas. Abstracts with Programs. GSA Annual Meeting in Indianapolis, Indiana, USA - 2018.

Steinhauer, E.S., M.F. Neill, L.M. Demott., J.T. Landrum, W. Schumacher, and P.C. Bennett. 2006. Hydrogeochemical and Hydrogeological Evidence for Blanco River Recharge of Jacob's Well, A Karst Spring in Hays County, Texas. Geological Society of America Abstracts with Programs, Vol. 38, No. 7, p. 435.

TBWE- Texas Board of Water Engineers. 1960. Channel Gain and Loss Investigations Texas Streams 1918-1958: Bulletin 5807 D, 270p.

Watson, J.A., B.B. Hunt, M.O. Gary, D.A. Wierman, B.A. Smith. 2014. Potentiometric Surface Investigation of the Middle Trinity Aquifer in Western Hays County, Texas: BSEACD Report of Investigations 2014-1002, October 2014, 21 p. 
Wierman, D.A., A.S. Broun, L. Llano, and A.H. Backus. 2008. Cypress Creek/Jacob's Well Hydrogeologic Report. Hays Trinity Groundwater Conservation District, December 2008.43 p. + tables + appendices

Wierman, D. A., Broun, A. S., Hunt, B. B. 2010. Hydrogeologic Atlas of the Hill Country Trinity Aquifer, Blanco, Hays, and Travis Counties, Central Texas. Hays-Trinity Groundwater Conservation District, United States. < https:// repositories.lib.utexas.edu/handle/2152/8977

Wierman, D., Hunt, B. 2018. Groundwater Level Monitoring Results for HTGCD Transducer Wells and Wimberley Valley Public Water Supply Wells, Hays County, TX. Meadows Center for Water and the Environment, Texas State University at San Marcos, TX. 